\title{
SYNOVECTOMY OF THE KNEE IN RHEUMATOID ARTHRITIS
}

\author{
BY \\ J. STEVENS AND G. A. WHITEFIELD \\ Glasgow, Scotland
}

Excision of the synovial membrane from a diseased knee joint was first recorded by Volkmann (1877), who treated a tuberculous infection in this way. Mignon (1900) removed the entire synovial membrane from the anterior compartment of a knee affected by "chronic traumatic arthritis" and obtained normal function. Occasional reports of single cases followed until Swett (1923) established the value of the procedure in "chronic infectious arthritis". Five of his seven patients had the operation on both knees and the results 6 months to 2 years later were very good in all but the one patient who gave no history of polyarthritis. Swett (1924) defined "chronic infectious arthritis" in terms that suggest that he was referring to rheumatoid arthritis and by that time he had performed synovectomy on 26 knees. His criteria for selection of patients were clearly given as well as an indication of the results which might be expected. At about the same time Jones (1923) stated that "arthritis deformans and the acutely proliferative type atrophic arthritis positively contraindicate synovectomy". Speed (1924) and Bernstein (1933) also emphasized these contraindications. Heyman (1928), Allison and Coonse (1929), and Painter (1932) all reported satisfactory results in small series of patients with chronic infectious arthritis. Boon-Itt (1930) claimed improvement in two-thirds of the $\mathbf{4 2}$ knees followed up after operation for chronic arthritis (probably rheumatoid). His review of the results reported up to that time confirmed that this was about the proportion of patients likely to benefit; 26 of the 86 synovectomies reviewed by Inge (1938) were performed for rheumatoid arthritis and only sixteen of these were relieved of symptoms whilst some were made worse. A similar proportion of good results was found by Ghormley and Cameron (1941) in 52 cases, by Pardee (1948) in 25 cases, by London (1955) in 32 cases, and by Mori and Ogawa (1963) in fifty cases. The technique of posterior soft tissue release described by Wilson (1929) was used in conjunction with anterior arthrotomy by Preston (1953) for crippling deformity of the knee, with satisfactory results in nine out of eleven patients. In the most recent report, that by Aidem and Baker (1964), there were 24 good results after synovectomy in 26 rheumatoid knees followed up for between 1 and 7 years. The authors concluded "that perhaps synovectomy of the knee joint should be performed more frequently in the patient with rheumatoid arthritis", thus reiterating the statement made by Swett (1924) 40 years earlier.

Our own experience with the procedure is reported here.

\section{Clinical Material}

The operation has been carried out on 102 knees in 79 patients, two of whom subsequently proved to have psoriatic arthritis, the remainder having definite rheumatoid arthritis by the American Rheumatism Association Classification (Ropes, Bennett, Cobb, Jacox, and Jessar, 1959). There were 21 men and 58 women; the distribution by age is shown in Fig. 1 .

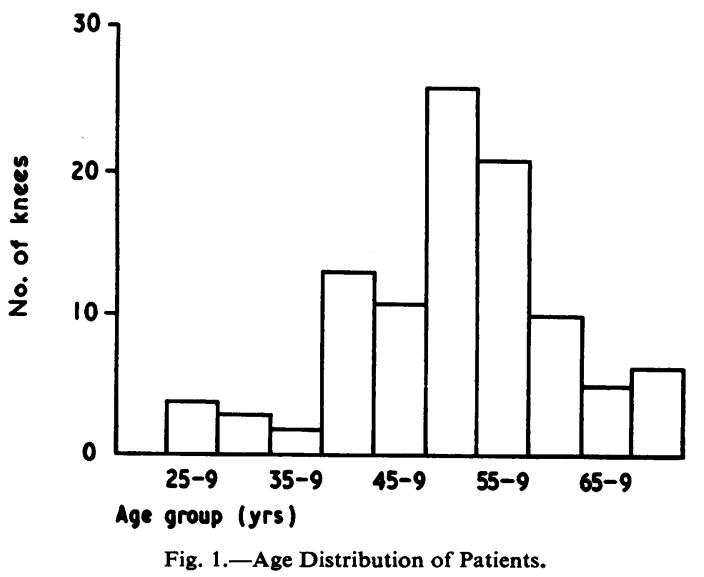


The two symptoms which affected knee function were pain and stiffness. Pain was graded as follows:

$$
\begin{aligned}
0= & \text { No pain } \\
+= & \text { Occasional pain (walking not notably } \\
& \text { restricted) } \\
++= & \begin{array}{l}
\text { Moderate pain (walking restricted to inter- } \\
\text { fere with routine activities) }
\end{array} \\
+++= & \text { Severe pain (walking restricted almost } \\
& \text { completely) }
\end{aligned}
$$

Table I shows the severity of pain experienced before operation related to the duration of involvement of the knee joint concerned. Pain was most severe in the recently affected joints, less severe in long-standing arthritis, and least severe when the disease was of moderate duration ( 1 to 5 years).

TABLE I

PRE-OPERATIVE PAIN

\begin{tabular}{l|c|c|c|c}
\hline $\begin{array}{c}\text { Pre-Operative } \\
\text { Pain }\end{array}$ & $\begin{array}{c}\text { No. of } \\
\text { Cases }\end{array}$ & \multicolumn{2}{|c}{ Duration of Knee Symptoms } \\
& & $<1$ & $1-5$ & $>5$ \\
\hline Mild & 6 & 0 & 0 & 6 \\
Moderate & 47 & 6 & 30 & 11 \\
Severe & 49 & 13 & 19 & 17 \\
\hline Total & 102 & 19 & 49 & 34 \\
\hline
\end{tabular}

The normal range of knee-joint movement was taken to be $0^{\circ}$ (full extension) to $130^{\circ}$ (full flexion) and limitation of flexion, limitation of extension, and total range were considered separately in the pre-operative assessment, all measurements being made with a protractor. The movements, related to duration of symptoms in the knee,

\begin{tabular}{|c|c|c|c|c|}
\hline \multirow{2}{*}{$\begin{array}{l}\text { Loss of } \\
\text { Flexion }\end{array}$} & \multirow{2}{*}{$\begin{array}{l}\text { No. of } \\
\text { Cases }\end{array}$} & \multicolumn{3}{|c|}{ Duration of Knee Symptoms } \\
\hline & & $<1$ & $1-5$ & $>5$ \\
\hline $\begin{aligned}< & 5^{\circ} \\
& 5-25^{\circ} \\
> & 25^{\circ}\end{aligned}$ & $\begin{array}{r}9 \\
27 \\
66\end{array}$ & $\begin{array}{l}4 \\
6 \\
9\end{array}$ & $\begin{array}{r}2 \\
17 \\
30\end{array}$ & $\begin{array}{r}3 \\
4 \\
27\end{array}$ \\
\hline Total & 102 & 19 & 49 & 34 \\
\hline
\end{tabular}
are given in Tables II, III, and IV. Long-standing disease was accompanied by more limitation of movement, and limitation of flexion occurred earlier and more exten-

\begin{tabular}{|c|c|c|c|c|}
\hline \multirow{2}{*}{$\begin{array}{l}\text { Loss of } \\
\text { Extension }\end{array}$} & \multirow{2}{*}{$\begin{array}{l}\text { No. of } \\
\text { Cases }\end{array}$} & \multicolumn{3}{|c|}{ Duration of Knee Symptoms } \\
\hline & & $<1$ & $1-5$ & $>5$ \\
\hline $\begin{array}{l}<5^{\circ} \\
5-25^{\circ} \\
>25^{\circ}\end{array}$ & $\begin{array}{l}20 \\
53 \\
29\end{array}$ & $\begin{array}{r}8 \\
10 \\
1\end{array}$ & $\begin{array}{l}11 \\
26 \\
12\end{array}$ & $\begin{array}{r}1 \\
17 \\
16\end{array}$ \\
\hline Total & 102 & 19 & 49 & 34 \\
\hline
\end{tabular}
sively than limitation of extension.

TABLE II

PRE-OPERATION MOVEMENT-LOSS OF FLEXION

TABLE III

PRE-OPERATIVE MOVEMENT-LOSS OF EXTENSION
TABLE IV

PRE-OPERATIVE MOVEMENT-TOTAL RANGE

\begin{tabular}{c|c|c|c}
\hline $\begin{array}{c}\text { Total } \\
\text { Movement }\end{array}$ & $\begin{array}{c}\text { No. of } \\
\text { Cases }\end{array}$ & \multicolumn{2}{|c}{ Duration of Knee Symptoms } \\
(yrs)
\end{tabular}

\section{Operative Technique and Post-operative Management}

All operations were performed under general anaesthesia with a pneumatic tourniquet applied to the thigh. With the knee extended, a median para-patellar approach was used, incising the joint capsule from the medial side of the insertion of the infra-patellar tendon well up into the quadriceps tendon along the line of insertion of the fibres of vastus medialis. The synovium was first separated in the supra-patellar pouch and then stripped distally in two portions in the medial and lateral para-condylar gutters as far as the articular margins of the patella and of the femoral condyles. The knee was then fully flexed, displacing the patella laterally and everting it. Any adhesions and pannus were then dissected from the articular surface and synovium was cleared from the intercondylar notch, the infra-patellar fat pad, the menisci, and the lateral recesses of the joint. At this stage it was often possible to remove a good deal of synovium from the posterior recess of the joint, picking it out piece-meal with curved artery forceps. In joints with severe flexion contracture the cruciate ligaments were excised, although this appeared to give no appreciable improvement in the degree of extension possible. The semilunar cartilages were often absent but when present were usually covered by pannus. This was carefully removed if the menisci themselves appeared relatively healthy, otherwise one or both menisci were removed. The patella was seldom removed but any osteophytes present were trimmed from its periphery and from the tibial and femoral condyles. At the end of this procedure minimal use was made of electro-cautery for haemostasis and the capsule was very carefully repaired with interrupted silk stitches, using two layers in the upper half of the incision. After skin closure, a Jones type of compression bandage was carefully applied.

In nineteen instances in which this operation gave insufficient return of passive extension, a posterior approach was made and the posterior capsule was completely divided from side to side. It was sometimes necessary also to divide the fascia lata and the origins of gastrocnemius and to lengthen the hamstring tendons.

One week after operation the compression bandage was removed and under general anaesthesia the joint was put through the fullest possible range of movement. At the same time, any significant haematoma was aspirated (this was required on only two occasions) and $25 \mathrm{mg}$. hydrocortisone were injected into the joint. For the next week 
knee movements were encouraged, particular attention being given to quadriceps drill. A second manipulation 2 or 3 weeks after the first was required in five patients. Depending on the rate of progress, weight bearing was allowed between 2 and 4 weeks after operation. In order that the effort of the patient could be concentrated on the rehabilitation of one knee at a time, bilateral simultaneous synovectomy was not performed in the second half of the series. Patients who were receiving corticosteroids at the time of operation were given increased dosage to cover the operation and the immediate post-operative period. Patients who had been treated with steroids for more than 6 weeks at any time before operation were also given a 10-day course of cortisone, starting 3 days before operation, followed by withdrawal over the next 3 weeks. This regime was found to be unnecessary in patients who had never taken corticosteroids since acute generalized exacerbation of the arthritis, resulting from the operation, was not encountered.

\section{Results}

The length of follow-up in the series is as follows:

$\begin{array}{lc}\quad \text { Time } & \text { No. of } \\ \text { ( } m \text { ths }) & \text { Knees } \\ 24 \text { or more } & 31 \\ 18 \text { or more } & 19 \\ 12 \text { or more } & 17 \\ 6 \text { or more } & 25 \\ \text { Less than } 6 & 9 \\ \text { Lost to follow-up } & 1\end{array}$

\section{Relief of Pain}

The most striking post-operative feature in these patients has been a dramatic relief of pain. This was immediate and was maintained throughout the rehabilitation programme in 93 knees. In only nine knees did a significant amount of pain $(++$ or +++ ) recur at the following intervals after operation:

No. of
Knees
2
1
2
2
2

Recurrence of pain appeared to be related to the pre-operative duration of inflammation and to the severity of this at the time of operation as indicated? in Table $\mathrm{V}$.

In one of these nine knees post-operative pain was associated with gross superimposed osteo-arthritiso related to an injury several years previously. In the remaining eight knees (in four patients), the returno of pain was accompanied by signs of acute rheuma ᄁᄁ toid arthritis, namely effusion, synovial thickening, increased skin temperature, and quadriceps inhibi. tion. One such knee was re-explored 15 months $\overrightarrow{.}$ after the original operation and had the appearance of acute rheumatoid arthritis with excess turbide synovial fluid containing fibrin flakes, a very thick ened and haemorrhagic synovial membrane with villous proliferation, and further destruction of articular cartilage. After this second operation symptoms were completely relieved for less than 6 months and the picture of acute arthritis again? returned.

\section{Change in Joint Movement}

Accurate measurements of movement 6 months़ after operation were recorded in 89 knees. The change in total range as compared with that founs before operation is presented in Fig. 2 (opposite) There was improvement in 63 , no change in eighto and decrease in movement in eighteen knees. Changes in flexion and extension, related to pre-operative restriction, are shown in Tables VI and VII (opposite)

Where the pre-operative limitation was smalf further loss was common after operation. The los was less than $10^{\circ}$ in ten of the twenty knees which lost flexion and in thirteen of the nineteen knees which lost extension after operation. On the otheo hand the greater the pre-operative stiffness, the higher was the proportion of knees which gaines movement and the greater was the extent of the improvement.

In order to judge whether the range of movement recorded 6 months after operation was maintained this was compared with the range recorded at 12 and 24 months after operation in the 52 and 25 knees respectively for which details were available

TABLE $\mathrm{V}$

RECURRENCE OF PAIN

\begin{tabular}{|c|c|c|c|c|c|c|}
\hline \multirow{2}{*}{ No. of Cases } & \multicolumn{3}{|c|}{ Duration of Symptoms (yrs) } & \multicolumn{3}{|c|}{ Inflammation } \\
\hline & $<1$ & $1-5$ & $>5$ & Severe & Moderate & Mild \\
\hline $\begin{array}{l}\text { With Pain } \\
\text { Total in Group }\end{array}$ & $\begin{array}{r}5 \\
19\end{array}$ & $\begin{array}{r}2 \\
49\end{array}$ & $\begin{array}{r}2 \\
34\end{array}$ & $\begin{array}{r}7 \\
37\end{array}$ & $\begin{array}{r}2 \\
47\end{array}$ & $\begin{array}{r}0 \\
18\end{array}$ \\
\hline
\end{tabular}




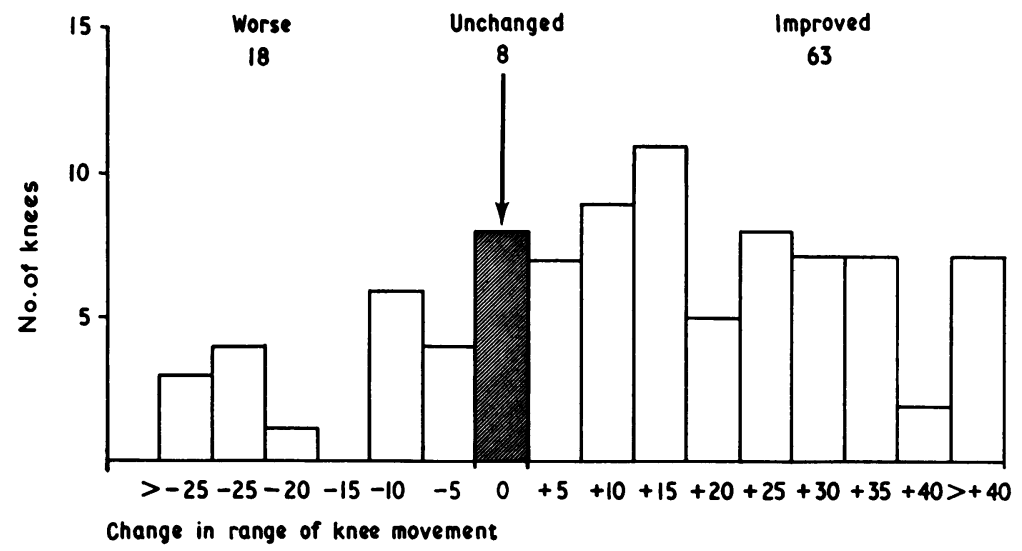

Fig. 2.-Change in Total Range of Knee Movement 6 Months after Operation.

TABLE VI

CHANGE IN FLEXION 6 MONTHS AFTER OPERATION

\begin{tabular}{|c|c|c|c|c|c|c|c|}
\hline \multirow{2}{*}{$\begin{array}{l}\text { Pre-operative } \\
\text { Loss }\end{array}$} & \multicolumn{3}{|c|}{ Loss } & \multirow{2}{*}{$\begin{array}{c}\text { No } \\
\text { Change }\end{array}$} & \multicolumn{3}{|c|}{ Gain } \\
\hline & $>30^{\circ}$ & $10-30^{\circ}$ & $<10^{\circ}$ & & $<10^{\circ}$ & $10-30^{\circ}$ & $>30^{\circ}$ \\
\hline $\begin{array}{l}<5^{\circ} \\
5-25^{\circ} \\
>25^{\circ}\end{array}$ & $\begin{array}{l}0 \\
2 \\
1\end{array}$ & $\begin{array}{l}0 \\
4 \\
3\end{array}$ & $\begin{array}{l}5 \\
1 \\
4\end{array}$ & $\begin{array}{l}2 \\
8 \\
8\end{array}$ & $\begin{array}{r}1 \\
4 \\
10\end{array}$ & $\begin{array}{r}0 \\
7 \\
19\end{array}$ & $\begin{array}{r}0 \\
0 \\
10\end{array}$ \\
\hline Total & 3 & 7 & 10 & 18 & 15 & 26 & 10 \\
\hline
\end{tabular}

TABLE VII

CHANGE IN EXTENSION 6 MONTHS AFTER OPERATION

\begin{tabular}{|c|c|c|c|c|c|c|c|}
\hline \multirow{2}{*}{$\begin{array}{l}\text { Pre-operative } \\
\text { Loss }\end{array}$} & \multicolumn{3}{|c|}{ Loss } & \multirow{2}{*}{$\begin{array}{c}\text { No } \\
\text { Change }\end{array}$} & \multicolumn{3}{|c|}{ Gain } \\
\hline & $>30$ & $10-30^{\circ}$ & $<10^{\circ}$ & & $<10^{\circ}$ & $10-30^{\circ}$ & $>30^{\circ}$ \\
\hline $\begin{aligned}< & 5^{\circ} \\
& 5-25^{\circ} \\
> & 25^{\circ}\end{aligned}$ & $\begin{array}{l}0 \\
1 \\
0\end{array}$ & $\begin{array}{l}2 \\
3 \\
0\end{array}$ & $\begin{array}{l}5 \\
8 \\
0\end{array}$ & $\begin{array}{r}10 \\
13 \\
1\end{array}$ & $\begin{array}{r}2 \\
14 \\
8\end{array}$ & $\begin{array}{r}0 \\
3 \\
13\end{array}$ & $\begin{array}{l}0 \\
0 \\
6\end{array}$ \\
\hline Total & 1 & 5 & 13 & 24 & 24 & 16 & 6 \\
\hline
\end{tabular}

Between 6 and 12 months, 21 knees gained between 5 and $40^{\circ}$ of movement, fifteen lost between 5 and $15^{\circ}$, and sixteen showed no change. Between 6 and 24 months, fourteen knees gained between 5 and $40^{\circ}$, nine lost between 5 and $25^{\circ}$, and two showed no change.

\section{Discussion}

Since the value of synovectomy of the knee affected by rheumatoid arthritis has been repeatedly established during the past 40 years or so, it is surprising that it is not undertaken more frequently.

The operation is a simple procedure, even when combined with posterior soft tissue release. When the latter is performed, for fixed flexion contracture, it must be sufficiently radical to permit the fully extended position to be reached at the end of the operation with no force whatsoever. Division or lengthening of hamstring tendons and removal of $\frac{9}{2}$ cruciate ligaments has not led to any significant $\rightarrow$ degree of instability. The single most important feature of the post-operative regime is an early $\stackrel{N}{\circ}$ manipulation under anaesthetic followed by active knee exercises in flexion and extension. Severely $\mathcal{N}^{\circ}$ wasted quadriceps, released from reflex inhibition, $\omega$ may continue to increase in power over a very long period. We believe that they do so more quickly if $\bullet$ the extensor mechanism is as near normal as possible $\mathbb{\mathscr { D }}$ and for this reason the patella has not been removed.

After excision of the synovial lining of a joint, regrowth occurs rapidly in experimental animals (Key, $\stackrel{\overrightarrow{\mathbb{D}}}{\mathrm{D}}$ 1925). A similar process occurs in the human $\frac{\rho}{\mathbb{Q}}$ rheumatoid joint (Swett, 1923) and in the one $\unrhd$ 
instance in which a second operation was performed in our series the new synovium was acutely affected by the rheumatoid process. Why this does not always occur is not clear, but it appeared to be commoner in joints inflamed for less than a year before operation. The immediate relief of pain following operation has been maintained in all but nine of our series. Some of the patients have been followed for only a few months but the relapse rate has not been any greater in patients followed for 2 years or more.

Gain in movement has been satisfactory. In acutely inflamed joints, loss of movement is largely due to reflex muscle spasm and can be expected to return when pain is relieved. In long-standing disease, intra- and extra-articular contractures may require release. The tendency in this series has been for movement to improve rather than to deteriorate in the long term.

Very broadly, the severity of rheumatoid inflammation of joints can be graded as "acute", "subacute", and "chronic". Although, in this series, recurrence of symptoms after synovectomy was most common in acutely-inflamed knees, the relapse rate was not so high as to contraindicate operation on these. The "sub-acute" stage appears to be the ideal time at which to remove the persistently inflamed synovial membrane to prevent the occurrence of the "chronic" stage when the degree of joint destruction makes the operation a salvage procedure. Even then a useful range of movement can be restored and this is particularly desirable when the hips as well as the knees are affected.

The overall clinical results in this series, as indicated by relief of pain, restoration of movement, and above all satisfaction of the patients, have been sufficiently encouraging to justify continuing with the procedure. The ideal method of assessment, a controlled trial, is at present being planned.

\section{Summary}

(1) Synovectomy was performed on 102 knees, of which 100 were affected by rheumatoid and two by psoriatic arthritis.

(2) The operation and post-operative management are described.

(3) Pain was relieved in all but nine knees, eight of which belonged to four patients who were operated upon when the arthritis was highly active and of recent onset.

(4) Of the 89 knees followed for 6 months only, eighteen lost movement, the amount lost exceeding $10^{\circ}$ in eight of them.
(5) Beyond 6 months after operation, improvement in function was commoner than deterioration.

(6) The results are regarded as good enough to advocate much wider practice of the operation.

We are grateful to Prof. Roland Barnes for his help in this work and to the many physicians who have referred patients to us for treatment.

\section{REFERENCES}

Aidem, H. P., and Baker, L. D. (1964). J. Amer. med. Ass., 187, 4.

Allison, N., and Coonse, G. K. (1929). Arch. Surg., 18, 824.

Bernstein, M. A. (1933). Ann. Surg., 98, 1096.

Boon-Itt, S. B. (1930). J. Bone Jt Surg., n.s. 12, 853.

Ghormley, R. K., and Cameron, D. M. (1941). Amer.J. Surg., n.s. 53, 455.

Heyman, C. H. (1928). Surg. Gynaec. Obstet., 46, 127.

Inge, G. A. L. (1938). J. Amer. med. Ass., 111, 2451.

Jones, E. (1923). Ibid., 81, 1579.

Key, J. A. (1925). J. Bone Jt Surg., n.s. 7, 793.

London, P. S. (1955). Ibid., 37-B, 392.

Mignon, A. (1900). Bull. Soc. Chir. Paris, 26, 1113.

Mori, M., and Ogawa, R. (1963). Arthr. and Rheum., 6, 130.

Painter, C. F. (1932). J. Bone Jt Surg., n.s. 14, 795.

Pardee, M. L. (1948). Ibid., 30-A, 908.

Preston, R. L. (1953). Ann. rheum. Dis., 12, 290.

Ropes, M. W., Bennett, G. A., Cobb, S. A., Jacox, R., and Jessar, R. A. (1959). Ibid., 18, 49.

Speed, J. S. (1924). J. Amer. med. Ass., 83, 1814.

Swett, P. P. (1923). J. Bone Jt Surg., n.s. 5, 110. (1924). Ibid., n.s. 6, 800.

Volkmann (1877). Quoted by Speed (1924).

Wilson, P. D. (1929). J. Bone Jt Surg., n.s. 11, 40.

La synovectomie du genou dans l'arthrite rhumatismale

\section{RÉSUMÉ}

(1) On proceda à la synovectomie sur 102 genoux, 윽 dont 100 furent atteints d'arthrite rhumatismale et les $>$ deux autres d'arthrite psoriasique.

(2) On décrit l'opération et les soins post-opératoires.

(3) La douleur fut soulagée dans tous les genoux sauf $N$ neuf; huit de ceux-ci appartenaient à quatre malades opérés alors que leur arthrite était très active et récente. $\omega$

(4) La mobilité fut réduite en 18 sur 89 genoux suivis pendant 6 mois seulement; cette réduction de l'amplitude du mouvement excéda $10^{\circ}$ en huit d'entre eux.

(5) Au delà de six mois après l'opération, l'améliora-'tion de la fonction était plus habituelle que sa détérioration.

(6) On croit que les résultats de cette opération sont $\frac{\rho}{\Phi}$ assez bons pour préconiser son emploi plus répandu. 
La sinovectomia de la rodilla en la artritis reumatoide

\section{SUMARIO}

(1) Se llevaron a cabo sinovectomias sobre 102 rodillas, cien de las cuales fueron afectas de artritis reumatoide y las dos demás de artritis psoriásica.

(2) Se describe la operación y los cuidados postoperatorios.

(3) El dolor fué aliviado en todas las rodillas con la excepción de nueve; ocho de estas pertenecían a cuatro enfermos con una artritis muy reciente y muy activa.
(4) La movilidad fué reducida en 18 de las 89 rodillas observadas solamente durante seis meses; en ocho rodillas esta reducción de la amplitud del movimiento excedió $10^{\circ}$.

(5) Después de seis meses desde la operación, la mejoría de la función fué más frecuente que la deterioración.

(6) Los resultados de esta operación se consideran bastante satisfactorios para preconizar su empleo más extensamente. 